\title{
AÇÃO DIRETA DE INCONSTITUCIONALIDADE 4275: UMA ANÁLISE SOB A ÓTICA DO ATIVISMO JUDICIAL E DAS QUESTÕES DE GÊNERO
}

\author{
DIRECT ACTION OF UNCONSTITUTIONALITY 4275: AN ANALYSIS UNDER THE VIEW OF \\ JUDICIAL ACTIVISM AND GENDER ISSUES
}

\section{Luana Paixão Dantas do Rosário}

Doutora em Direito Público pela Universidade Federal da Bahia - UFBA. Professora Adjunta de Direito Constitucional da Universidade Estadual de Santa Cruz - UESC. Líder do Grupo de Pesquisa Jurisdição Constitucional, Hermenêutica e Democracia - JCHD, certificado no DgP/CNPq, espelho: dgp.cnpq.br/dgp/espelhogrupo/7039068957089890. Editora da revista Diké.

E-mail: lpdrosario@uesc.br

\section{Manuela Macedo Leal}

Graduada em Direito pela Universidade Estadual de Santa Cruz (UESC). Pesquisadora no Grupo de Pesquisa Jurisdição Constitucional, Hermenêutica e Democracia - JCHD, certificado no DgP/CNPq, espelho: dgp.cnpq.br/dgp/espelhogrupo/7039068957089890. Advogada OAB/BA nº 61663.

E-mail: manuelaleal47@gmail.com

Recebido em: 24/08/2019

Aprovado em: 15/04/2020

RESUMO: A pesquisa abordou o perfil teórico ativista da Suprema Corte Brasileira no julgamento da Ação Direta de Inconstitucionalidade n. 4275, na ótica do ativismo judicial em Garapon e Dworkin, ao passo em que teceu considerações à autocontenção e ao garantismo. Explicitou, ainda, o perfil da abordagem teórica do gênero e do controle dos corpos em procedimentos de interdição a partir de Butler e Foucault. Utilizou para análise os votos do ministro relator Marco Aurélio, do ministro Alexandre de Moraes e do ministro Edson Fachin. O problema residiu em analisar se existiu ativismo judicial, a partir do marco teórico proposto, no julgamento da ADI n. 4275 e se este ativismo rompeu com a matriz teórica de gênero binária e heteronormativa dominante. A hipótese inicial era a de que houve ativismo judicial no julgamento. O método foi o hermenêutico fenomenológico e, quanto à técnica, foi realizada pesquisa documental, com análise qualitativa e hermenêutica do conteúdo dos votos e teor do julgamento da ADI 4275 presentes no site do STF, e pesquisa bibliográfica do marco teórico. O resultado da pesquisa apontou para a confirmação do perfil ativista da Suprema Corte, embora não aberto, totalmente, ao pluralismo e à diversidade das questões de gênero.

Palavras-chave: Supremo Tribunal Federal. Transexualidade. Direitos Fundamentais. Ativismo judicial.

ABSTRACT: The research approached the activist theoretical profile of the Brazilian Supreme Court in the judgment of the Direct Action of Unconstitutionality n. 4275, in the perspective of the judicial activism in Garapon and Dworkin, 
while it made considerations for self-restraint and guarantee. . It also explained the profile of the theoretical approach of gender and the control of bodies in procedures of interdiction from Butler and Foucault. It used for analysis the votes of the minister rapporteur Marco Aurélio, of the minister Alexandre de Moraes and the minister Edson Fachin. The problem was to analyze whether there was judicial activism, based on the proposed theoretical framework, in the ADI n. 4275 and if this activism broke with the theoretical matrix of dominant binary and heteronormative gender. The initial hypothesis was that there was judicial activism on trial. The method was the phenomenological hermeneutic and, as far as the technique was concerned, a documentary research was carried out, with qualitative and hermeneutical analysis of the content of the votes and content of the ADI n. 4275 judgment present on the STF website, and bibliographic research of the theoretical framework. The result of the research pointed to the confirmation of the activist profile of the Supreme Court, although not open, completely, to the pluralism and diversity of the gender issues.

Keywords: Federal Court of Justice. Transsexuality. Fundamental rights. Judicial activism.

SUMÁRIO: Introdução. 1 Questões de gênero: a identidade trans. 2 Ativismo judicial: Definições e contrapontos. 2.1 Antoine Garapon, ativismo e o esvaziamento da instituição política. 2.2 Ronald Dworkin, ativismo hermenêutico e as questões de principio. 2.3 Ativismo, autocontenção e garantismo. 3 Análise da ADI 4275. 3.1 Voto do relator Ministro Marco Aurélio. 3.1.1 O procedimento de jurisdição voluntária com requisitos: pessoas trans não cirurgiadas. 3.2 Voto do Ministro Alexandre de Moraes. 3.3 Voto do Ministro Edson Fachin. 3.4 Regulamentação e reflexos da ADI n. 4275: O Provimento n. 73 do Conselho Nacional de Justiça e o julgamento do Recurso Extraordinário n. 670422. Conclusões. Referências.

\section{INTRODUÇÃO}

Ante o silêncio normativo brasileiro quanto aos direitos das pessoas que transitam em sua identidade de gênero, no que toca, inclusive, ao direito a alteração do prenome e sexo (na verdade, seria gênero, mas a petição inicial da Ação Direta de Inconstitucionalidade (ADI) no 4275 trata como alteração do sexo e a tese de repercussão geral é também fixada neste sentido - sexo, e não gênero -, em demonstração de conformidade à matriz de gênero binária dominante adequada à genitalização do discurso da racionalidade hegemônica) no registro civil para sua adequação ao nome social, o que ocasionava, por sinal, decisões judiciais conflitantes e uma realidade de incerteza quanto a efetivação dos direitos fundamentais e da personalidade dessas pessoas, em 21 de julho de 2009 foi proposta pela Procuradoria Geral da República (PGR) a ADI n 4275 (BRASIL, 2018). Todo o quadro vivenciado levou o Supremo Tribunal Federal a, em 01 de março de 2018, dar provimento a ADI n 4275 (BRASIL, 2018), utilizando-se do princípio da dignidade da pessoa humana e da técnica da interpretação conforme a Constituição para finalmente reconhecer o direito a modificação do prenome e sexo das pessoas trans em seus registros civis.

O problema desta pesquisa reside em analisar se, de fato, existiu ativismo judicial - a partir do marco teórico do ativismo hermenêutico de Ronald Dworkin (2010), das contribuições de Antoine Garapon (2001) e da síntese de Luís Roberto Barroso (2009) - no julgamento da ADI 4275, tendo em vista que a Suprema Corte Brasileira, em mais uma decisão histórica na afirmação dos direitos de minorias (cita-se a ADPF $\mathrm{n}^{\circ} 132$ - casamento homoafetivo, e a ADPF $\mathrm{n}^{\circ} 186$ - cotas raciais em universidades públicas), aqui compreendidas como grupos histórica, econômica e socialmente discriminados, pareceu mais uma vez revelar seu ativismo judicial em direitos fundamentais. E reside também em analisar se o ativismo presente nos discursos decisórios nos votos dos ministros de fato rompeu com a matriz de gênero binária e heteronormativa dominante. 
Daí, então, o interesse em pesquisar o perfil teórico do discurso do Tribunal em favor da diversidade e pluralismo das questões de gênero. Na análise foram utilizados os conceitos de heteronormatividade e performances de gênero, em Judith Butler (2003), e de regime de verdades e interdições, em Michael Foucault (2015). No percurso da pesquisa foram também utilizadas compreensões da transexualidade pela socióloga brasileira Berenice Bento (2008).

O método utilizado foi o hermenêutico fenomenológico e, quanto a técnica, foi o da pesquisa documental, através da qual retirou-se e analisou-se hermenêutica e qualitativamente excertos dos votos dos ministros Marco Aurélio, relator; Alexandre de Moraes e Edson Fachin, disponíveis no site do Supremo Tribunal Federal. Houve também a técnica da pesquisa bibliográfica para a consulta dos marcos teóricos propostos.

A pesquisa se justifica pela sua relevância social, afirmação de direitos de minorias, e pertinência teórica do ativismo judicial exercido através do controle de constitucionalidade brasileiro que se abre para a efetivação de direitos fundamentais, e se demonstra integrador e simbólico, como se pode observar dos perfis de julgamento das Arguições de Descumprimento de Preceito Fundamental $n^{\circ} 132$ - casamento homoafetivo (BRASIL, 2011) e $n^{\circ} 186$ - cotas raciais em universidade públicas (BRASIL, 2012).

Com a finalidade de atingir o objetivo proposto, de identificar o perfil teórico ativista da Suprema Corte e o perfil teórico das abordagens das questões de gênero e interdições, será necessário, inicialmente, conceituar gênero, sexo e transexualidade. Nesse ínterim, serão visitados os procedimentos de exclusão e os regimes de verdade para se compreender a normatização dos temas interditados. Discutir-se-á o ativismo judicial como esvaziamento da instituição política, em Antoine Garapon (2001), e como questão de princípio, em Ronald Dworkin (2010), enquanto serão feitas breves considerações acerca da autocontenção e do garantismo. A partir daí, será possível narrar breve panorama da propositura e pertinência da ADI n 4275 e passar-se-á à análise dos votos do Ministro Relator Marco Aurélio, do Ministro Alexandre de Moraes ${ }^{1}$, que seguiu parcialmente o relator e condicionou o pedido de alteração à autorização judicial e do Ministro Edson Fachin, que não o condicionou à autorização judicial.

\section{QUESTÕES DE GENERO: A IDENTIDADE TRANS}

Os direitos das pessoas que transitam em sua identidade de gênero não se encontram na pauta jurídica há tanto tempo. É pauta tão recente e eivada de questionamentos quanto o olhar ainda depositado a estas existências. Em latim, trans significa "do outro lado". Esse significado carrega imenso simbolismo a aqueles que se entendem do outro lado, em estação diferente, silenciados por uma sociedade que se orienta majoritariamente pela lógica binária de identidade de gênero atrelada ao sexo e seus marcadores biológicos ou simbólicos.

Obviamente, o discurso que constrói as normas de gênero impostas é o discurso de poder, o discurso binarista e heterossexual, que impõe a constituição do gênero atrelada ao caráter biológico, e apenas considera "normal" a performance masculina e a feminina. É justamente este discurso que reduz as pessoas trans à margem, que patologiza ${ }^{2}$ e medicamentaliza os corpos que transitam entre os gêneros.

\footnotetext{
${ }^{1}$ Oportunamente, agradecemos ao Gabinete do Ministro Alexandre de Moraes pela disponibilização do voto em tempo hábil, autorizada pelo referido Ministro, antes mesmo da publicação do Acórdão da ADI 4275 - que, até o momento de produção desse artigo, ainda não havia sido publicado -, com a finalidade de subsidiar a análise qualitativa e hermenêutica nesta pesquisa científica.

${ }^{2}$ Até o mês de junho de 2018, a transexualidade estava inserida na Classificação Estatística Internacional de Doenças e Problemas Relacionados com a Saúde (CID), a CID-10, desde 1990, entendida como um distúrbio mental. A Organização Mundial da Saúde (OMS) anunciou nova edição da CID no dia 18/06/2018, intitulada de CID-11, na qual a transexualidade deixa de figurar como "transtorno da personalidade e do comportamento" e é incluída no catálogo como "incongruência de gênero", dentro da categoria de condições relativas à saúde sexual. Na prática, a transexualidade deixa de ser compreendida como uma doença mental, no entanto, ainda assim, passível de constatação Revista de Direito Brasileira | Florianópolis, SC | v. 26 | n. 10 | p. 25-45 | Mai./Ago. 2020
} 
Joan Scott (1990) relembra que a conceituação de gênero é atrelada a experiência histórica, pois entende o gênero como "um elemento constitutivo de relações sociais fundadas sobre as diferenças percebidas entre os sexos, e [...] um primeiro modo de dar significado às relações de poder" (SCOTT, 1990, p. 5) O poder, então, é exercido sobre o gênero como forma de domínio político.

Judith Butler (2003), em compreensão semelhante à de Scott (1990), na qual busca historicizar a relação entre corpo e sexo, ainda na década de 90, ressalta que a noção de gênero, compreendida como atributo cultural construído para o feminino e o masculino que parte da demarcação biológica (binarismo) como instrumento para estabelecer posições hierárquicas, apresenta limitações teóricas aos estudos feministas. Propõe, então, uma teorização que rompe com a dicotomia sexo versus gênero. Teoriza a compreensão do gênero como um artifício flutuante, independente do sexo, que é performático, não somente em número de dois, como o afirma a ótica binarista que está atrelada a diferenciação sexual, que reproduz a ideia de validação de apenas duas performances: o corpo-homem (masculino) e o corpo-mulher (feminino).

Butler (2003) entende que o gênero é construído e operacionalizado na linguagem e pela linguagem. A partir de Foucault, empreende que o gênero é o resultado do discurso, das relações que produzem poder. Cria a teoria da performatividade de gênero, assumindo que o gênero é constituído pela repetição de atos, signos e gestos. O gênero, então, não é um dado, mas uma sequência de atos que constitui o sujeito. Portanto, existem diversas performances possíveis de gênero, no entanto o discurso hegemônico só permite a perpetuação de duas delas, dentro da lógica binária. A razão de ser desta "imposição" binária do gênero parte dos limites discursivos da experiência das performances de gênero, eis que estes limites são estabelecidos pelo discurso cultural hegemônico, baseados nas estruturas binárias (masculino/feminino, macho/fêmea, homem/mulher, pênis/vagina) impostas pela linguagem da racionalidade universal.

Ao teorizar os limites deste discurso, Butler (2003) define o que pode se compreender como heteronormatividade, que se relaciona com o conceito de heterossexualidade compulsória de Adrienne Rich (2012), e se traduz na imposição hegemônica da heterossexualidade como norma de conduta. "A instituição de uma heterossexualidade compulsória e naturalizada exige e regula o gênero como uma relação binária em que o termo masculino se diferencia do termo feminino, realizando-se esta diferenciação por meio das práticas do desejo heterossexual" (BUTLER, 2003, p. 53). Nesta interpretação, norma significa um padrão de conduta social, cultural, comportamental e ético construído e naturalizado, que é justamente o padrão heterossexual, que silencia qualquer outra performance fora da regra na qual a experiência da sexualidade só pode ser vivida na lógica binária.

Para Berenice Bento (2008), a Teoria Queer de Butler (2003) questiona severamente a tradição binária atribuída às teorizações de gênero fincadas na dicotomia sexo (biológico) versus gênero (cultural). Seguindo a linha performática da Teoria Queer, afirma:

o que diferencia as performances das/os mulheres/homens biológicas/os das/os transexuais é a legitimidade que as normas de gênero conferem a cada uma delas, instaurando, a partir daí uma disputa discursiva e uma produção incessante de discursos sobre a legitimidade de algumas existirem e de outras serem silenciadas e eliminadas (BENTO, 2008, p. 48).

Assim, as normas de gênero impostas hegemonicamente por uma heterossexualidade compulsória deslegitimam as pessoas transexuais, silenciam-nas, colocam-nas à margem. Portanto,

médica. A CID-11 deve ser implementada até $1^{\circ}$ de janeiro de 2022. Será analisada, ademais, a decisão na ADI 4275/DF, que ainda observou a transexualidade sob o viés de doença mental, haja vista que o julgamento ocorreu em março/2018, fortemente influenciado pelo discurso patologizante.

Revista de Direito Brasileira | Florianópolis, SC | v. 26 | n. 10 | p. 25-45 | Mai./Ago. 2020 
esses corpos "anormais" são considerados doentes, necessitando, para sua "normalização", de um indulto médico e de uma permissão jurídica, nesta ótica binária.

Diversamente, na perspectiva da Teoria Queer, é dispensada a lógica da normalização e, com isso, a necessidade do indulto médico. Desta maneira, não faz sentido, acolhida a compreensão queer de gênero, para a afirmação da identidade da pessoa transexual, a cirurgia de redesignação sexual, visto que múltiplas são as possibilidades de performatizar o gênero. Inclusive, segundo Foucault (1998), este ato de vincular comportamento ao sexo, gênero à genitália, que define o feminino pela presença da vagina e o masculino pela presença do pênis, remonta o séc. XIX, quando o sexo passou a conter a verdade última de nós mesmos.

Berenice Bento, ao tentar decifrar quais mudanças sociais levaram a tal vinculação, indica que "a transexualidade não é uma experiência identitária a-histórica, ao contrário, revela com toda dor e dramaticidade os limites de uma ordem de gênero que se fundamenta na diferença sexual" (BENTO, 2008, p. 24). Desta maneira, o discurso de poder foi o responsável por apagar o conteúdo histórico da experiência transexual com a finalidade de determinar que a verdade última dos sujeitos termina em seu sexo, mantendo a lógica binária na qual a ordem social deve ser ditada pela natureza:

A sexualidade, as performances de gênero, a subjetividade, a identidade de gênero constitui campos marcados pela diferença sexual. Nessa lógica dicotômica, não é possível fazer deslocamentos. O masculino e o feminino só conseguem encontrar sua inteligibilidade quando referenciados à diferença sexual. (BENTO, 2008, p. $31)$.

Bento busca definir um conceito para a transexualidade e sugere que "a transexualidade é uma experiência identitária, caracterizada pelo conflito com as normas de gênero" (BENTO, 2008, p. 18). A autora, inclusive, entende a travestilidade e os transgêneros como expressões identitárias que também revelam conflito com as normas de gênero, normas que são fundadas pela heterossexualidade e idealizações. Este é um conceito deveras complicado, mas, sobretudo, ilustrativo, posto que considerar a transexualidade como uma experiência identitária caracterizada pelo conflito com as normas de gênero leva em conta, e reproduz, a matriz teórica de gênero binária e heteronormativa, com a qual a Teoria Queer de Butler (2003) rompe, pois compreende a transexualidade como mais uma das possibilidades de performatizar o gênero.

[...] se os atributos e atos do gênero, as várias maneiras como o corpo mostra ou produz sua significação cultural, são performativos, então não há identidade preexistente pela qual um ato ou atributo possa ser medido: não haveria atos de gênero verdadeiros ou falsos, reais ou distorcidos, e a postulação de uma identidade de gênero verdadeira se revelaria uma ficção reguladora (BUTLER, 2003, p. 201).

Portanto, reduzir o gênero ao campo da demarcação biológica, como o faz a construção binária, revela-se uma ficção reguladora que entende como possíveis apenas duas performances de gênero, na qual as pessoas que transitam entre os gêneros (entre elas, as pessoas transexuais) não se encaixam, ficam à margem. O conteúdo político e hegemônico que patologiza as pessoas trans, panorama enfrentado por estes indivíduos na complexa teia social, esbarra no discurso do binarismo, ou, como anotado por Judith Butler (2003), da heteronormatividade. Depreende-se, então, que essa redução acontece no campo do discurso, da linguagem, através de procedimentos de exclusão e imposições de regimes de verdade. O sujeito que detém o poder de falar e de fazer reproduzir o seu discurso é o sujeito que se comporta de acordo com as normas de gênero impostas, a heteronormatividade, como constrói Butler (2003). Assim, as pessoas que transitam entre as 
normas de gênero (binarismo) são consideradas desviantes, e, em termos foucaultianos, têm seus discursos interditados.

A interdição, segundo Michel Foucault (2015), é um dos procedimentos de exclusão do sujeito no discurso. Ao excluir determinados sujeitos do discurso, determina quem detém o poder de falar e de fazer reproduzir o seu discurso, delimita o "direito privilegiado ou exclusivo do sujeito que fala" (FOUCAULT, 2015, p. 9). Quem tem o direito de falar não pode falar sobre qualquer assunto, assim como pessoas, existem temas que são interditados. No presente caso, é privilegiado o sujeito que se comporta de acordo com as normas de gênero impostas, com a heteronormatividade, como constrói Butler (2003). Assim, as pessoas que transitam entre as normas de gênero são consideradas desviantes, e, em consequência, interditadas.

Sabe-se bem que não se tem o direito de dizer tudo, que não se pode falar de tudo em qualquer circunstância, que qualquer um, enfim, não pode falar de qualquer coisa. Tabu do objeto, ritual da circunstância, direito privilegiado ou exclusivo do sujeito que fala: temos aí o jogo de três tipos de interdições que se cruzam, se reforçam ou se compensam, formando uma grade complexa que não cessa de se modificar (FOUCAULT, 2015, p. 9).

A construção dessa anormalidade e marginalização, entende-se, perpassa pela criação e imposição do que Foucault (1979) intitula 'regimes de verdade', que são os tipos de discurso que uma sociedade acolhe e faz funcionar como verdadeiros. A verdade, aqui, é referendada pelo controle e medicalização dos corpos, que atua para consolidar a constituição dos sujeitos. Para Foucault, "o controle da sociedade sobre os indivíduos não se opera simplesmente pela consciência ou pela ideologia, mas começa no corpo, com o corpo" (FOUCAULT, 1979, p. 81). Desta forma, defende que o corpo é uma 'realidade biopolítica' e a medicina uma 'estratégia biopolítica' e por biopolítica entende o procedimento de formatação e controle das pessoas pelo Estado moderno. Logo, o regime de saber produz limitações (as verdades do conhecimento) e faz operar como o sujeito deve comportar-se para encaixar-se na normalidade imposta pelo regime de verdade, verdade produzida não somente pelo discurso médico, mas também pelo discurso jurídico. Tomase, inclusive, a liberdade para apontar que o discurso jurídico por demais vezes se apropria do discurso médico para endossar sua autoridade, como se observará do conteúdo do julgamento da Ação Direta de Inconstitucionalidade 4275 (BRASIL, 2018).

Os discursos de poder da medicina e do direito, da medicalização e da normatização constroem a todo momento verdades que dão (ou não) qualidade de sujeitos aos corpos transeuntes. As justificativas e reflexos dessa permissão jurídica e indulto médico serão adiante analisadas. $\mathrm{O}$ silêncio legislativo a respeito dos direitos pleiteados pelas pessoas trans fazem parte dos temas interditados e do cistema dos regimes de verdade. A reivindicação desses direitos ao Judiciário por esses corpos marginais é espaço de disputa pelo discurso e de ativismo.

\section{ATIVISMO JUDICIAL: DEFINIÇÕES E CONTRAPONTOS}

\subsection{Antoine Garapon, ativismo e o esvaziamento da Instituição Política}

Diante do protagonismo contemporâneo assumido pelo Poder Judiciário em efetivar direitos fundamentais sobretudo de minorias, de sua função contramajoritária e da própria crise de representatividade do parlamento, o ativismo judicial é compreendido como um dos efeitos da própria instituição democrática, segundo Antoine Garapon (2001). Fenômeno de controversa definição pela imprecisão de seu significado, inclusive dentre seus defensores, o ativismo judicial é compreendido, nesta abordagem, a partir da conceituação do Ministro Roberto Barroso (2009), como uma postura proativa de interpretação Constitucional assumida pelo Judiciário na concretização dos fins constitucionais. 
Garapon, no final do século XX, entendeu o ativismo judicial como um dos reflexos mais aparentes da inflação do judiciário de demandas políticas de uma estrutura democrática que entra em crise, o que intitula de "a derrubada do homem democrático" (GARAPON, 2001, p. 26). Nessa linha, tenta explicar o fenômeno do 'ativismo judiciário' através do que entende como transformação do regime democrático. Entende que quanto mais a democracia se emancipa, mais procura na justiça uma espécie de memória, salvaguarda. Assim é que "o juiz passa a ser o último guardião de promessas tanto para o sujeito como para a comunidade política" (GARAPON, 2001, p. 27).

Para Garapon, as elites republicanas não conseguiram manter as expectativas de moral e de justiça democráticos. O estopim do ativismo jurídico "[...] não se trata de uma transferência de soberania para o juiz, mas sobretudo de uma transformação da democracia" (GARAPON, 2001, p. 39). A origem desse movimento encontra-se no investimento do direito no imaginário democrático, posto que o direito se converteu na nova linguagem com a qual "se formulam as demandas políticas que, desiludidas com um Estado inativo, se voltam maciçamente para a justiça" (GARAPON, 2001, p. 39) A justiça, assim, passa a ocupar um espaço simbólico e integrador dentro das sociedades democráticas que, ausentes de autoridade, necessitam de um ritual e um procedimento para referendar seu complexo engendramento.

No entanto, há perigos que não são negados pelo autor. Essa inversão de lugares e a supervalorização da atuação jurisdicional pela mídia pode culminar com uma falsa sensação de heroísmo aos juízes, e o excesso de direito pode inclusive desnaturalizar a democracia. "A justiça não pode se colocar no lugar da política" (GARAPON, 2001, p. 53), e, investida com tantas esperanças de dizer o que é justo e garantir a moral numa sociedade tão complexa, a justiça corre o risco de implodir e quebrar com o simbolismo que carrega, que ventila sua autoridade.

O que bem salienta Garapon é o perigo da despolitização da democracia através do ativismo judiciário, nesse cenário em que o juiz se torna o novo "anjo da democracia" (GARAPON, 2001, p. 74), reclamando um status de privilégio, em posição de domínio inacessível à crítica popular. Por outro lado, deixar a questão de direitos fundamentais das minorias e, neste caso, de pessoas trans à mercê da deliberação da maioria é deveras arriscado. Para compreender os contornos desta questão democrática, passa-se a abordar a teoria hermenêutica de Ronald Dworkin no que toca às questões de princípios.

\subsection{Ronald Dworkin, ativismo hermenêutico e as questões de princípios}

As pessoas trans, sujeitos de direitos, por sua marginalização histórica, social e econômica, podem ser compreendidas, nesta abordagem, como minorias. Em Dworkin (2010), quando pessoas são identificadas como minorias se exige um tratamento equânime por parte de uma maioria, posto que essa minoria possui direitos (mesmo que não ditos pela norma-regra) que são consequência direta de sua dignidade, questão de princípio. Partindo deste entendimento, é que Dworkin (2010) utiliza comumente em seu vocabulário técnico a expressão right to equal concern and respect, que se traduz em um princípio geral no qual todas as pessoas merecem igualdade de consideração e respeito de tal forma que "as leis não devem estar constituídas de maneira que coloque pessoas em desvantagem" (DWORKIN, 2010, p. 281).

Em sua filosofia política, Dworkin (2010) compreende que os cidadãos possuem direitos além daqueles que as leis lhes outorgam, e traz como implicações desta instituição de direitos contra o governo duas ideias importantes. A primeira, a poderosa ideia da dignidade da pessoa humana, "pressupõe que existem maneiras de tratar um homem que são incompatíveis com seu reconhecimento como um membro pleno da comunidade humana, e sustenta que tal tratamento é profundamente injusto" (DWORKIN, 2010, p. 304-305). A segunda é a ideia de igualdade política, oriunda da constituição democrática de uma sociedade, e pressupõe que "os membros mais frágeis 
da comunidade política têm direito à mesma consideração e ao mesmo respeito que o governo concede a seus membros mais poderosos" (DWORKIN, 2010, p. 305).

A ideia de igualdade trazida por Dworkin (2010) traduz-se em um trunfo que uma minoria possui contra uma maioria, de maneira que uma lei não pode ser considerada justa se ferir o direito, no sentido forte, desta minoria, mesmo que sua justificação se dê em benefício geral. Em favor desta tese, articula:

A parte principal do direito - a parte que define e executa as políticas sociais, econômicas e externas - não pode ser neutra. Deve afirmar, em sua maior parte, o ponto de vista da maioria sobre a natureza do bem comum. Portanto, a instituição dos direitos é crucial, pois representa a promessa da maioria às minorias de que sua dignidade e igualdade serão respeitadas. (DWORKIN, 2010, p. 314)

$\mathrm{O}$ argumento segundo o qual "uma minoria tem direito à igualdade de consideração e respeito, é um argumento de princípio" (DWORKIN, 2010, p. 130). Para o autor, Direito é princípio. E por princípio entende os direitos individuais que cada ser humano possui. Política, para Dworkin (2010), se trata de um conjunto de objetivos e metas para se alcançar tais princípios. Nesta teia, o autor defende a tese de que as decisões judiciais nos casos difíceis (hard cases) devem ser geradas por princípios, e não por políticas.

Não obstante, os juízes não agem arbitrariamente, conforme suas convicções, eles estão imersos em uma tradição, "a história institucional faz parte do pano de fundo que qualquer juízo plausível sobre os direitos de um indivíduo deve levar em consideração" (DWORKIN, 2010, p. 136). Ademais, os juízes, como qualquer autoridade política, encontram-se sujeitos à 'doutrina da responsabilidade política' (DWORKIN, 2010, p. 137), na qual só podem tomar decisões que possam justificar no âmbito de uma teoria política que justifique as outras decisões que porventura se proponham a tomar.

Dworkin traz, então, a concepção do direito como integridade, uma questão de princípio, na qual "as proposições jurídicas são verdadeiras se constam, ou se derivam, dos princípios de justiça, equidade e devido processo legal que oferecem a melhor interpretação construtiva da prática jurídica da comunidade" (DWORKIN, 2010, p. 272). Assim, a integridade visa garantir uma coerência de princípio, que se torna nova fonte do direito, a partir da qual o juiz deve buscar

identificar quais princípios justificam as leis e os precedentes para formar o seu juízo. É justamente com a finalidade de analisar a formação do juízo plausível sobre as questões de princípio que envolvem a efetuação de direitos fundamentais que se passará a analisar hermenêutica e qualitativamente o julgamento da Ação Direta de Inconstitucionalidade no 4275 (BRASIL, 2018), responsável pela efetivação dos direitos de uma minoria ignorada pela pauta política. Antes, contudo, necessário ponderar acerca de algumas perspectivas que se contrapõem ao ativismo judicial.

\subsection{Ativismo, autocontenção e garantismo}

O marco teórico do ativismo judicial tem oposição consagrada nas teorias do self restraint e autocontenção judicial, cujos maiores expoentes, cujos maiores expoentes, em nossa ótica, são Cass Sunstein (2011), Jhon Hart Ely (2010) e Robert Dahl (2012). De modo geral, o que sustenta a autocontenção judicial é a ideia de que não cabe ao Poder Judiciário refazer as escolhas feitas no espaço político deliberativo.

O procedimentalismo de John Hart Ely (2010) defende que, em vez de buscar decisões substantivas do que é melhor, os juízes devem salvaguardar os procedimentos/processos democráticos, sem a intenção de determinar os valores fundantes de uma comunidade. Para Ely, "numa democracia representativa, as determinações de valor devem ser feitas pelos representantes 
eleitos; e, se a maioria realmente desaprová-los, poderá destituí-los através do voto” (ELY, 2010, p. 137).

Para o minimalismo judicial de Robert Dahl, "o máximo que até o melhor sistema judicial pode garantir é a justiça procedimental; ele não pode garantir a justiça substantiva” (DAHL, 2012, p. 257-58).

No projeto minimalista de Sunstein (2011), a posição institucional dos juízes deve ser a mais modesta possível, ao admitir as suas limitações cognitivas e as consequências de suas decisões. Trata-se do autorreconhecimento epistêmico de seu lugar e papel, guiado pela preocupação de que os juízes exerçam a atividade de legislador e pela qual a resolução das grandes questões ficaria a cargo das instituições políticas deliberativas.

Em nosso entendimento, concepções procedimentalistas pecam em supervalorizar o espaço representativo de deliberação política em sociedades assimétricas, e, ainda, por descuidar de que as Constituições contemporâneas fundem o juízo do que é devido ao do que é melhor e o exigem normativamente, de modo que o desafio interpretativo de concretizar direitos fundamentais, com o imperativo democrático da inclusão das minorias, tradicionalmente excluídas do espaço deliberativo, pode demandar uma postura ativista, alargando a própria concepção de democracia.

Outro marco teórico que tem sido apontado por alguns como contrário ao ativismo judicial, vide a Carta de Jundiai ${ }^{3}$, um manifesto de juristas, é o garantismo. No entanto, essa é uma visão incompleta do fenômeno do ativismo judicial. O garantismo é uma teoria que visa a efetivação de direitos e garantias fundamentais. $\mathrm{O}$ ativismo judicial, tal como por nós apresentado também parte de igual pressuposto, inclusive deve ter neste o seu parâmetro de funcionamento. Na lição de Ferrajoli (2010), o garantismo visa uma adequação entre o modelo constitucional e a aplicação das normas infraconstitucionais; é um padrão normativo que busca a efetividade de um sistema de garantias, e, neste ínterim, apontar para os eventuais desvios na busca desta finalidade. $\mathrm{O}$ ativismo judicial, tal como aqui descrito, também busca a concretização e efetividade de direitos e garantias fundamentais. Ocorre que, para isto, muitas vezes, a concretização precisa ser ativista. Em outras palavras, ser garantista pode implicar a necessidade de uma postura ativista na concretização dos direitos fundamentais.

A concepção mais restritiva do garantismo, aquela pela qual efetivar as garantias está relacionada com realizar uma devida ou taxativa interpretação da norma, está muito atrelada ao Direito Penal, de onde, aliás, vêm os garantistas, em princípio. Isto porque, no Direito Penal, contra o poder punitivo do Estado, as interpretações devem ser restritivas e taxativas. No entanto, no Direito Constitucional, de natureza extremamente política e conteúdos vagos e axiológicos, a imposição de restrições interpretativas pode significar exatamente o oposto do que se busca com a efetivação das garantias. Eis onde reside o desafio interpretativo dos conteúdos constitucionais.

\section{ANÁLISE DA ADI 4275/DF}

A Ação Direta de Inconstitucionalidade ${ }^{4} n^{\circ} 4275$ (BRASIL, 2018) foi proposta pela Procuradoria Geral da República (PGR), para que fosse dada interpretação conforme a Constituição Federal ao artigo 58 da Lei n $^{\circ} 6.015$ (BRASIL, 1973), que dispõe sobre os registros públicos, no sentido de ser possível a alteração de prenome e sexo no registro civil mediante averbação no registro original, independentemente de cirurgia de transgenitalização (BRASIL, 2018, online). O conteúdo da norma contestada se referia à possibilidade de alteração do prenome por apelidos

\footnotetext{
${ }^{3}$ Elaborada durante o Colóquio Internacional - No ensejo do primeiro ano de vigência do CPC-2015, realizado em agosto/2016, capitaneado pelo Instituto Pan-americano de Direito Processual (IPDP), pela Associação Brasileira de Direito Processual (ABDPro) e pela Revista Brasileira de Direito Processual (RBDPro).

${ }^{4}$ Segundo Dirley da Cunha Jr. (2014) cuida-se de uma ação de controle concentrado-principal de constitucionalidade para a defesa genérica de todas as normas constitucionais, conhecida também como ação genérica.
}

Revista de Direito Brasileira | Florianópolis, SC | v. 26 | n. 10 | p. 25-45 | Mai./Ago. 2020 
públicos notórios, que, segundo a PGR, abrangeria o prenome social dos transexuais ${ }^{5}$ (ressalte-se que, embora o pedido inicial tenha se referido aos transexuais, houve ampliação, em sede de julgamento, para os transgêneros), e entendia a PGR ser incongruente a modificação do prenome sem a correspondente alteração do sexo no registro civil, suscitando a interpretação do preceito em jogo em consonância com os artigos $1^{\circ}$, inciso III, $3^{\circ}$, inciso IV, e $5^{\circ}$, caput e inciso X, da Constituição da República Federativa do Brasil de 1988 (BRASIL, 1988).

Definitivamente julgada em 01 de março de 2018, teve como relator o Ministro Marco Aurélio. Todos os ministros votaram pelo reconhecimento do direito, ou seja, pela alteração do "sexo" e prenome no registro civil, e, embora tenham ampliado o direito de alteração do assentamento civil aos transgêneros, mantiveram somente a alteração do sexo, o que indica uma concepção binarista e heteronormativa do gênero. A maioria (6 dos 10 ministros, posto que impedido o Ministro Dias Toffolli) entendeu que a alteração prescinde de autorização judicial, e foi esta a tese fixada no julgamento. Neste sentido, votaram Edson Fachin, Luiz Roberto Barroso, Rosa Weber, Luiz Fux, Celso de Mello e a então presidente da Corte, Carmen Lúcia. O relator, Marco Aurélio, condicionou a alteração a procedimento de jurisdição voluntária ${ }^{6}$, os ministros Alexandre de Moraes, Ricardo Lewandowski e Gilmar Mendes seguiram o relator, embora com ressalvas. Destarte, percebe-se duas orientações de voto: a que condiciona à autorização judicial e a que prescinde desta. Salienta-se, ainda, que não houve controvérsia acerca de submissão dos transexuais à cirurgia de transgenitalização como condição à referida alteração de registro, todos os ministros entenderam que tal submissão feriria a dignidade da pessoa humana.

A partir desta orientação, os votos escolhidos para análise foram, primeiro, o voto do Ministro Marco Aurélio, relator da ADI 4275, que se manifestou favorável à submissão da alteração do registro a procedimento de jurisdição voluntária. Em seguida, selecionou-se o voto do Ministro Alexandre de Moraes, primeiro a votar após o relator, em concordância parcial, impondo autorização judicial. Após, optou-se pelo voto do Ministro Edson Fachin, primeiro a votar em dissonância com o relator e não impor qualquer tipo de autorização judicial como condicionante, voto que foi seguido majoritariamente e revelou abertura dos pontos de fuga ao cistema.

\subsection{Voto do relator Ministro Marco Aurélio}

O Ministro Marco Aurélio, relator da ADI 4275, votou favoravelmente à alteração do registro civil condicionando-a ao procedimento de jurisdição voluntária. Inicialmente, salientou ser perfeitamente possível a interpretação conforme a Constituição (técnica hermenêutica que parte da filtragem constitucional) pela qual concluiu que a Suprema Corte é absolutamente competente para examinar o alcance da expressão polissêmica da norma impugnada. Neste trecho já se percebe o viés hermeneuticamente ativista da decisão na interpretação da Lei de Registros Públicos, eis que reconhece a lacuna da lei e preenche criativamente o seu significado.

[...] o artigo 58 da Lei ${ }^{\circ}$ 6.015/1973 permite a técnica de interpretação conforme à Carta Federal. Embora lacônico, o dispositivo encerra situação excepcional na qual autorizada a substituição do prenome por apelido público notório. $\mathrm{O}$ exame do alcance desta última expressão revela a polissemia da norma, sobretudo a partir das balizas do Texto Maior. A ressaltar essa óptica, o preceito tem sido utilizado por magistrados para afastar o direito à mudança do prenome e gênero averbados

\footnotetext{
${ }^{5}$ Entende-se por transexuais as pessoas que possuem identidade de gênero diferente do sexo biológico, enquanto os transgêneros são entendidos como pessoas que transitam entre os gêneros. Ver JESUS, Jaqueline Gomes de. Orientações sobre a população trans-gênero: conceitos e termos. Brasília: Autor, 2012. 24p. Disponível em: < HTTPS://www.sertao.ufg.br/up/16/0/ORIENTA\%C3\%95ES_POPULA\%87\%C3\%83O_TRANS.pdf?1334065989> Acesso em: 02 nov. 2018.

${ }^{6}$ No qual não há lide, não há ação judicial, trata-se de solicitação livre da parte a um juiz que referenda o ato. Ver DIDIER JÚNIOR, Fredie. Curso de direito processual civil. 17. ed. Salvador: JusPODIVM, 2015. 1v.

Revista de Direito Brasileira | Florianópolis, SC | v. 26 | n. 10 | p. 25-45 | Mai./Ago. 2020
} 
relativamente a transexual, consoante revelam as decisões judiciais anexadas à petição inicial. (AURÉLIO, 2018, p. 6, grifo nosso).

$\mathrm{Na}$ argumentação do Ministro Marco Aurélio é possível identificar a reflexão de Garapon (2001) em relação a implosão de demandas no judiciário da agenda democrática e do desabamento do homem político, isto porque o Supremo Tribunal Federal atuou, neste caso, como um garantidor de promessas. A característica principal desta afirmação está no efeito vinculante da decisão tomada e, ainda, no fato deste pleito em particular demonstrar o esvaziamento da esfera política, fenômeno próprio das democracias contemporâneas, segundo Garapon (2001). O parlamento brasileiro, em sua maioria conservador, não fez garantir direitos fundamentais a uma minoria marginalizada; pauta relevante e esquecida. O silêncio da instituição política levou a Corte a utilizar a interpretação conforme a Constituição Federal, dando sentido à norma através de uma filtragem constitucional, na qual o princípio propulsor da síntese do argumento do relator foi a dignidade da pessoa humana, que permitiu anunciar direitos legítimos a um grupo aparentemente esquecido e marginalizado pela sociedade brasileira. $\mathrm{O}$ ministro ressalta:

[...] o tema é sensível e envolve valores constitucionais de importância maior. Cabe indagar: mostra-se legítimo recusar a transexuais o direito à alteração do prenome e gênero no registro civil? A resposta é desenganadamente negativa. É tempo de a coletividade atentar para a insuficiência de critérios morfológicos para afirmação da identidade de gênero, considerada a dignidade da pessoa humana. Descabe potencializar o inaceitável estranhamento relativo a situações divergentes do padrão imposto pela sociedade para marginalizar cidadãos, negando-lhes o exercício de direitos fundamentais. (AURÉLIO, 2018, p. 7-8, grifo nosso).

Observa-se, já neste trecho, que Marco Aurélio compreende a insuficiência da questão da diferenciação sexual como marco para a afirmação da identidade de gênero, justamente o discurso binarista imposto pelo discurso da racionalidade hegemônica, como aponta Butler (2003). Assenta esse entendimento na própria dignidade da pessoa humana, epicentro axiológico do Estado Democrático de Direito.

Neste ponto, é possível perceber a reflexão da filosofia de Ronald Dworkin (2010) na argumentação do ministro, levando-se em conta os direitos morais que as minorias possuem contra a maioria. Por se tratar de uma sociedade democrática, a questão da dignidade humana e da igualdade se traduzem em um trunfo que as minorias, neste caso, as pessoas transexuais, possuem contra a maioria que se demonstrou inerte através da via política (congressistas representativos) e, diante da norma em vigor, considerada injusta nestes parâmetros de igualdade, é necessário que o Judiciário diga o direito moral fundante à norma, o direito advindo deste pacto no qual uma sociedade que coloca o bem comum em alta conta deve ter para com aqueles que não têm sua dignidade observada ou garantida, que fazem parte desta mesma sociedade.

é dever do Poder Público, no Estado Democrático de Direito, promover a convivência pacífica com o outro, na seara do pluralismo, sem admitir o crivo da maioria sobre escolhas exclusivamente morais, sobretudo quando decorrem de inafastáveis circunstâncias próprias à constituição somática da pessoa. Cabe a cada qual trilhar a respectiva jornada, arcando com a responsabilidade imposta pela própria consciência, na busca pelos objetivos que se propôs a cumprir. (AURÉLIO, 2018, p. 9).

O ministro Marco Aurélio condicionou a retificação de registro a procedimento de jurisdição voluntária sem a exigência de requisitos médicos se as pessoas trans em questão tiverem se submetido à cirurgia de transgenitalização, exigindo, a seu turno, uma série de requisitos de

Revista de Direito Brasileira | Florianópolis, SC | v. 26 | n. 10 | p. 25-45 | Mai./Ago. 2020 
ordem médica para as pessoas trans não cirurgiadas. Percebe-se que o ministro reforça a demarcação biológica do gênero ao propor requisitos para auferir, com segurança, a transexualidade, como se essa "condição" fosse passível de diagnóstico.

4.1.1 O procedimento de jurisdição voluntária com requisitos: pessoas trans não cirurgiadas

A utilização do discurso do poder da medicina para a definição com "segurança" da identidade trans pelo Direito, como pretendeu o ministro relator em seu voto, reforça a percepção de uma interdição (FOUCAULT, 2015) e a necessidade de um procedimento que controle o indivíduo. Dessa forma, o discurso médico é visivelmente utilizado como a realidade biopolítica, procedimento de controle Estatal, afirmada por Foucault (1979), confirmadora do padrão comportamental imposto.

o critério morfológico, embora carente de mitigação, ainda é parâmetro relevante para a identificação de cidadãos. Nos casos em que não realizada a cirurgia de transgenitalização, a alteração do assentamento deve ser precedida da verificação de critérios técnicos aptos a comprovar a transexualidade. Mostra-se adequado observar o que preconizado na Resolução $n^{\circ} 1.955$, de 3 de setembro de 2010, do Conselho Federal de Medicina. A norma dispõe sobre a cirurgia de transgenitalização, estabelecendo os requisitos a serem atendidos pelo paciente a fim de redefinir, com segurança, os caracteres sexuais. (AURÉLIO, 2018, p. 10, grifo nosso).

O discurso utilizado neste trecho, em especial, reforça a ideia da genitalização, da ótica binária imposta pela heterossexualidade compulsória (BUTLER, 2003). Somente consideram-se validadas, pelo discurso hegemônico, as duas performances atreladas à genitália, que frequentemente reforçam a ideia do corpo-homem e do corpo-mulher. Nenhuma outra performance pode ser compreendida e concebida por este discurso jurídico que mantém o perfil hegemônico, nesta interdição.

A medicina como estratégia biopolítica, conforme Foucault (1979), é utilizada pelo ministro quando propõe como parâmetro uma resolução do Conselho Federal de Medicina, que utiliza o termo patologizante "transexualismo" a fim de estabelecer requisitos a serem auferidos no procedimento de jurisdição voluntária proposto, para garantir a segurança na alteração de registro civil de pessoa transexual que não passou por cirurgia de transgenitalização.

Tem-se, aqui, uma controvérsia. Ao mesmo tempo em que defende, em seu voto, que submeter as pessoas transexuais a cirurgia de transgenitalização como condição para alteração registral trata-se de imposição de mutilação, e ferimento à dignidade da pessoa humana, o ministro condiciona a alteração do registro civil destas pessoas trans "não mutiladas"7 a uma aferição médica, a um diagnóstico, e utiliza requisitos da resolução do Conselho Federal de Medicina que busca justamente regulamentar essas cirurgias de transgenitalização. A partir da resolução, o ministro cria requisitos para a alteração do registro de prenome e gênero para pessoas trans que não passam pela cirurgia de transgenitalização.

[...] a alteração do assentamento de pessoa não submetida à transgenitalização deve ser condicionada ao preenchimento dos seguintes requisitos: (i) idade mínima de 21 [...] e (ii) diagnóstico médico de transexualismo, consoante os critérios do artigo $3^{\circ}$ da Resolução $n^{\circ} 1.955 / 2010$, do Conselho Federal de Medicina, por equipe multidisciplinar constituída por médico psiquiatra, cirurgião, endocrinologista, psicólogo e assistente social, após, no mínimo, dois anos de acompanhamento conjunto. (AURÉLIO, 2018, p. 11, grifo nosso)

\footnotetext{
${ }^{7}$ Expressão utilizada em plenária de julgamento pelo ministro relator. Ver STF, Pleno - Retomado julgamento de ADI sobre alteração de registro civil sem mudança de sexo. Direto do Plenário. Brasília: TV Justiça, 01 mar. 2018. Disponível em: <https://www.youtube.com/watch?v=sRhdrUUaYMg> Acesso em: 04 jun. 2018.
} 
Presente está o discurso de poder analisado por Foucault (1979), principalmente no tocante ao controle exercido pela sociedade nos corpos dos seus integrantes. Este controle se revela no condicionamento estabelecido pelo ministro de requisitos médicos para definir, com segurança, a existência de uma identidade de gênero, identidade esta reveladora de uma performatividade que foge a lógica binária, e, logo, a racionalidade do discurso hegemônico. Embora utilize a dignidade da pessoa humana como principal argumentação para dar procedência parcial ao pedido, o ministro não se abre às pluralidades desta dignidade, traduzida por Dworkin (2010) como uma ideia central da instituição dos direitos, na qual sustenta que existem maneiras de tratar uma pessoa que são incompatíveis com seu reconhecimento como um membro pleno da comunidade humana, e que tal tratamento é profundamente injusto. Tem-se, aqui, um parâmetro de tratamento injusto, que mantém uma lógica patologizante dos corpos que transitam em sua identidade de gênero.

\subsection{Voto do Ministro Alexandre de Moraes: alteração condicionada a autorização judicial}

O Ministro Alexandre de Moraes votou, logo após o relator, favoravelmente à alteração do registro civil, porém, condicionando-a à autorização judicial, mas sem impor qualquer requisito médico ou necessidade de cirurgia de transgenitalização. $\mathrm{O}$ ministro utiliza em sua argumentação bases no direito comparado (casos do Tribunal Constitucional Alemão; legislação Italiana, GrãBretanha, Espanhola, Portuguesa e Argentina) para sustentar a desnecessidade de cirurgia de redesignação sexual como condição para alteração do registro civil. Sustenta, adiante, ser inconcebível a supressão do assentamento originário, justificando se tratar de violação da autenticidade, segurança e eficácia dos registros, bem como para assegurar direito de terceiros.

O ministro propõe a abrangência da interpretação não somente aos transexuais, mas também aos transgêneros, entendendo ser consequência necessária da dignidade da pessoa humana, e passa a ser o primeiro a comentar em plenário neste sentido. Julga, então, procedente o pedido e, na sessão plenária, após o voto do ministro Fachin, que não impôs autorização judicial para a alteração do registro, o ministro Moraes propõe aditamento ao seu voto para manifestar-se a favor da autorização judicial, e justifica:

A necessidade da decisão judicial de jurisdição voluntária não decorre, ao meu ver, de nenhuma espécie de discriminação, porque ela é prevista desde a lei de 1973 para qualquer alteração de prenome. É prevista para garantir uma maior segurança jurídica, tanto que a mudança do prenome exige a decisão judicial e eu diria, até, por uma questão de segurança jurídica. (MORAES, 2018, p. 7).

É assim que, entendendo ser uma questão de segurança jurídica, o ministro profere seu aditamento, condicionando a alteração, assim como o relator, a uma decisão judicial. A opção de Moraes é de não inovar. Essa opção está atrelada à tradição positivista, e tanto está que o ministro condiciona a opção a uma leitura normativa. Pode-se perceber, da teoria de Dworkin (2010), que, embora o juiz esteja obrigado a seguir a moralidade institucional a fim de garantir a integridade, não está obrigado a não inovar por este motivo - no entanto, questiona-se mesmo se haveria moralidade institucional a orientar a cautela interpretativa diante da ausência de precedentes na matéria -; ao contrário, o juiz, quando está diante de um caso difícil, no qual há direitos fundamentais em jogo e insuficiência legislativa para a garantia destes direitos, deve agir com vistas a garanti-los, mesmo que não estejam expressos, mesmo que precise inovar, a fim de garantir os direitos das minorias, as questões de princípios. Há, neste caso em especial, a necessidade de inovar.

Dessa opção por não inovar, observa-se o caráter de autocontenção do Ministro, que com seu argumento de segurança jurídica parece impor a ideia de que não cabe ao Judiciário invadir a esfera de deliberação política. Esta posição revela-se inclusive procedimentalista, na qual Moraes

Revista de Direito Brasileira | Florianópolis, SC | v. 26 | n. 10 | p. 25-45 | Mai./Ago. 2020 
parece se apropriar da atitude defendida por John Hart Ely (2010), buscando uma decisão que salvaguarde os procedimentos democráticos sem demonstrar resoluções substantivas do que é melhor para a comunidade objeto do pleito. Portanto, Moraes foge de demonstrar determinações valorativas, o que escapa e ignora a complexidade de se garantir direitos a uma minoria que não se viu representada nas instituições políticas deliberativas e requer, nesse sentido, a intervenção da esfera judicial como última saída. A autocontenção nega, nesse caso, a própria complexidade da democracia, eis que necessária uma posição ativista para se garantir os direitos dessa minoria.

\subsection{Voto do Ministro Edson Fachin: alteração incondicionada à autorização judicial}

Após o ministro Alexandre de Moraes, manifestou-se o ministro Edson Fachin, que não apresentou, em seu voto, qualquer condicionamento a autorização judicial/procedimento de jurisdição voluntária. Seu voto rompe bruscamente a linha de raciocínio que estava se estabelecendo no julgamento. Na argumentação de Fachin pode-se inferir a teoria dos direitos de Dworkin (2010), e a força gravitacional dos precedentes. O ministro inicia seu voto justificando que a base de sua interpretação está fincada nos precedentes da Suprema Corte, assim:

[...] o voto se estriba em precedentes que formam jurisprudência deste Tribunal e, especialmente, da Corte Interamericana de Direitos Humanos; especificamente citam-se os seguintes: o RE 670.422, Rel. Ministro Dias Toffoli; a ADPF 54, Rel. Ministro Marco Aurélio; Opinião Consultiva 24/17 da Corte Interamericana de Direitos Humanos sobre Identidade de Gênero e Igualdade e Não-Discriminação. (FACHIN, 2018, p. 2-3).

Observa-se interpretação calcada em questões de princípio, conforme traduz Dworkin (2010). O ministro analisa o sistema constitucional como um todo, a fim de checar se sua teoria se harmoniza com a moralidade institucional que é pano de fundo do seu juízo. Este movimento, que foi realizado pelo ministro Edson Fachin, amolda-se à teoria desenvolvida por Dworkin (2010), que entende o direito como integridade, nesta capacidade que os juízes devem ter para tratar casos semelhantes de maneira semelhante e deixar transparecer, através do método interpretativo, a argumentação de princípio por trás das decisões tomadas anteriormente. Para justificar a interpretação criativa da norma, e o recebimento da Ação Direta de Inconstitucionalidade, Fachin utiliza-se da moralidade institucional do Supremo Tribunal Federal, ao afirmar que:

[...] na esteira de pacífica jurisprudência desta Corte, eventual indicação imprecisão da técnica decisória a ser adotada pelo Supremo Tribunal Federal não inviabiliza o conhecimento da ação direta. Isso porque o Tribunal "não está condicionado, no desempenho de sua atividade jurisdicional, pelas razões de ordem jurídica invocadas como suporte da pretensão de inconstitucionalidade deduzida pelo autor da ação direta" (ADI 561-MC, Rel. Min. Celso de Mello, Pleno, DJ 23.03.2001). Ademais, a técnica decisória objeto do pedido desta ação direta, embora se afaste do tradicional conceito de interpretação conforme, segundo o qual a interpretação deve ficar adstrita aos limites da intenção legislativa, não é inédita nesta Corte. Com efeito, a interpretação conforme pode implicar o deferimento de "decisão manipulativa de efeito aditivo", como, de resto, já reconheceu o Tribunal, quando do julgamento da ADPF 54, Rel. Ministro Marco Aurélio, Pleno, DJe 29.04.2013. (FACHIN, 2018, p. 5)

Nesta esteira de raciocínio, o ministro reconhece que a decisão decorrente do controle de constitucionalidade teria efeito aditivo, e aqui toma-se a liberdade para afirmar que este efeito revela o próprio ativismo judicial realizado pela Corte. Depreende-se da argumentação de Fachin uma das reflexões feitas por Garapon (2001), quando o ministro reflete a importância da atuação 
jurisdicional na complexa teia democrática, na qual o Estado se depara com as mais variadas camadas e implicações dos direitos às liberdades e garantias individuais, e o juiz, com seu olhar empático e solidário, guardião de uma promessa, precisa analisar essa situação complexa e garantir um direito que de fato existe. É o que se depreende:

Evidencia-se, assim, com olhar solidário e empático sobre o outro, que inadmitir a alteração do gênero no assento de registro civil é atitude absolutamente violadora de sua dignidade e de sua liberdade de ser, na medida em que não reconhece sua identidade sexual, negando-lhe o pleno exercício de sua afirmação pública. (FACHIN, 2018, p. 15, grifo nosso)

Com isto, pode-se afirmar que a propositura da ADI 4275 é um efeito direto da evolução da democracia, que passa a dar visibilidade aos que antes eram invisíveis às instituições políticas formais. O judiciário, ao atuar neste caso, deixa clara a inércia legislativa, manipulando a interpretação de uma lei que já não produz eficácia ante os novos engendramentos sociais. A questão é tão complexa que o ministro, ao justificar seu posicionamento, precisa dizer o óbvio:

[...] a identidade de gênero é manifestação da própria personalidade da pessoa humana e, como tal, cabe ao Estado apenas o papel de reconhecê-la, nunca de constituí-la. Ademais, se ao Estado cabe apenas o reconhecimento, é-lhe vedado exigir ou condicionar a livre expressão da personalidade a um procedimento médico ou laudo psicológico que exijam de indivíduos assunção de um papel de vítima de determinada condição. [...]A pessoa não deve provar o que é e o Estado não deve condicionar a expressão da identidade a qualquer tipo de modelo, ainda que meramente procedimental. (FACHIN, 2018, p. 15-16, grifo nosso)

O ministro avança em relação ao proposto pelo relator, quando não condiciona a alteração a qualquer requisito médico ou jurídico, indicando que o julgamento não deve apenas se adequar à Constituição, mas também ao Pacto San José da Costa Rica. Portanto, segue a Opinião Consultiva 24/17 da Corte Interamericana de Direitos Humanos sobre Identidade de Gênero e Igualdade e Não-Discriminação, de 24 de novembro de 2017, que indica que os procedimentos para alterações de registro civil dos Estados devem estar de acordo com a identidade de gênero autopercebida. E, portanto:

[...] os Estados têm a possibilidade de estabelecer e decidir sobre o procedimento mais adequado de conformidade com as características próprias de cada contexto e de seu direito interno, os trâmites e procedimentos para a mudança de nome, adequação de imagem e retificação da referência ao sexo ou ao gênero, em todos os registros e em todos os documento de identidade para que estejam conformes à identidade de gênero autopercebidas, independentemente de sua natureza jurisdicional ou materialmente administrativa (FACHIN, 2018, p. 15, grifo nosso).

O ministro, ao trazer concepção contemporânea acerca da identidade de gênero que demonstra absoluta harmonização com a dignidade da pessoa humana, contribui para o debate de maneira aberta e plural. Finda a argumentação, Fachin não apresenta qualquer condicionamento a alteração do registro civil, seja ela médica ou jurídica. Vota para que a alteração ocorra diretamente no registro civil, através de procedimento cartorário, opinião que foi majoritária, embora com apenas 02 votos de diferença, o que demonstra certa resistência da composição da Corte em se abrir às pluralidades das questões de gênero.

Fachin fornece uma interpretação que permite concluir, a partir do que foi posto acerca do garantismo, de que a postura ativista foi justamente a que se demonstrou necessária para se efetivar 
garantias. Diferentemente da concepção garantista de limitação da esfera interpretativa, neste julgamento, para propiciar a afirmação dos direitos fundamentais das pessoas trans se mostrou imprescindível uma postura ativista, sem a qual não se obteria outro resultado. O conteúdo político esvaziado nas esferas representativas de uma sociedade assistemática e complexa levou o intérprete constitucional a ser garantista justamente por meio do ativismo, ao contrário do defendido por algumas correntes. Portanto, demonstra-se que, por diversas ocasiões, é preciso ir além da taxatividade para garantir e não o contrário.

A posição adotada por Fachin, que foi majoritária, numa leitura debruçada na acepção de território, a partir de Deleuze e Guattari (2010), soa como fruto da desterritorialização do discurso. Território, em uma apropriação poética do conceito, é tudo aquilo que o sujeito controla, que está dentro, que pode ser medido, que é submisso, não desvia. O discurso controlado, aquele que possui margens definidas, é justamente o discurso heteronormativo, binarista. Tudo o que está fora dele é desterritorializado. Deleuze e Guattari (2010) fornecem um exemplo bastante simples para entender a territorialização, basta imaginar que um bastão é um galho desterritorializado. Aqui, os limites do bastão, da desterritorialização, encontram-se justamente no discurso insubmisso das pessoas trans, pessoas interditadas e seus corpos, como refletido em Foucault (1979), biopolíticos, controlados.

A fissura do território se deu no próprio impulsionamento da propositura da ADI n. 4275, fruto da luta dos movimentos sociais LGBTQ+, e aqui citam-se os dois importantes representantes que levaram a PGR a propor a Ação Direta de Inconstitucionalidade: a Associação Brasileira de Gays, Lésbicas, Bissexuais, Travestis e Transexuais (ABGLT) e a Articulação Nacional de Travestis e Transexuais (ANTRA).

A primeira organização política de travestis da América Latina ${ }^{8}$ foi instituída em 02 de maio de 1992, quando se fundou a Associação de Travestis e Liberados (ASTRAL). A construção de organizações políticas como a ASTRAL se deu pela reunião da comunidade interessada em resposta à violência policial exercida pelo governo nos locais de prostituição e a inserção em programa de prevenção à AIDS. O enfoque governamental dado a grupos de pessoas trans partia unicamente dos programas de prevenção à AIDS, não havia enfoque para questões que já eram bandeira naquela época, a exemplo do nome social. Já o espaço formal das pessoas trans em movimentos unificados se deu na ABGLT, Associação que nasceu em 31 de janeiro de 1995, fruto das lutas pela redemocratização e há 25 anos permanece resistindo pelo reconhecimento das pautas LGBTQ+ nas instituições políticas formais.

Dos esforços para a afirmação da existência e luta por direitos da comunidade LGBTQ+ como um todo, há outras visibilidades. Em 28 de junho de 1997 foi realizada a $1^{\text {a }}$ Parada do Orgulho LGBT de São Paulo, sob o tema "somos muitos, estamos em todas as profissões". Em dezembro de 2000, na cidade de Curitiba, a organização de uma rede nacional de ONGs de travestis e transexuais se concretiza na criação da Articulação Nacional de Travestis, Transexuais e Transgêneros (ANTRA), e que atualmente configura-se como a maior rede de travestis e transexuais da América Latina (CARVALHO, M.; CARRARA, S., 2013). Embora existam representatividades e linha de frente na luta pelos corpos trans, o Brasil é o país que mais mata a população transgênero no mundo. Segundo o Mapa dos Assassinatos de Travestis e Transexuais no Brasil em $2017^{9}$, pesquisa desenvolvida pela ANTRA, apenas em 2017 foram 129 casos de homicídios. Significa dizer que, a cada 48h, uma pessoa trans é morta no Brasil. Este dado cruel e

\footnotetext{
${ }^{8}$ As informações sobre os grupos e organizações políticas aqui reproduzidas foram retiradas de um estudo realizado em 2009/2010, a partir de relatos das lideranças dos movimentos. Ver CARVALHO, Mario; CARRARA, Sérgio. Em direção a um futuro trans? Contribuição para a história do movimento de travestis e transexuais no Brasil. In: Sexualidad, Salud y Sociedad: Revista Latinoamericana. d. 2, n. 14, 2013, p. 319-351. Disponível em: <https://www.e-publicacoes.uerj.br/index.php/SexualidadSaludySociedad/article/view/6862/4940> Acesso em: 23 nov. 2018.

9 Disponível em: <https://antrabrasil.files.wordpress.com/2018/02/relatc3b3rio-mapa-dos-assassinatos-2017antra.pdf> Acesso em: 25 nov. 2018.
}

Revista de Direito Brasileira | Florianópolis, SC | v. 26 | n. 10 | p. 25-45 | Mai./Ago. 2020 
o cenário enfrentado, todos os dias, pelas pessoas trans são motivos para endurecer ainda mais a frente de resistência.

Apesar dos tristes e inaceitáveis índices, as conquistas obtidas pelos movimentos são reflexos de sua luta, a exemplo da alteração do registro civil que é pauta antiga do movimento trans e da recente interpretação dada pelo Tribunal Superior Eleitoral, em 2018, à chamada Lei das Eleições, de 1997, que exige um mínimo de 30\% de candidaturas femininas nas eleições (a partir da nova interpretação, mulheres trans podem ser incluídas na cota mínima para mulheres, assim como homens trans, na porcentagem dos homens).

Os movimentos sociais são encarados como "ações sociais coletivas de caráter sociopolítico e cultural que viabilizam formas distintas de a população se organizar e expressar suas demandas" (GOHN, 2011, p. 335) que agem como resistência à exclusão e lutam pela inclusão social. Na concretude, existem dois tipos de ações que podem ser desenvolvidas: diretas (mobilizações, passeatas, marchas, etc) e indiretas. Observa-se, no caso concreto, que a ação direta do movimento trans, em conjunto ao movimento LGBTQ+, gerou impacto na ação indireta, a representação jurídica. A pressão realizada pelos diversos representantes do movimento embalou o julgamento da ADI n. 4275, e levou, inclusive, à realização de um movimento de desterritorialização praticado pelo ministro Fachin, que em seu voto caminhou na contramão do discurso racional hegemônico.

A luta incessante e árdua dos movimentos sociais LGBTQ+ pelo reconhecimento da dignidade dessas pessoas foi justamente o que incitou a fissura do território, que se abriu, timidamente, mas finalmente, para desterritorializar.

\subsection{Regulamentação e reflexos da ADI n. 4275: o Provimento n. 73 do Conselho Nacional de} Justiça e o julgamento do Recurso Extraordinário n. 670422

Definitivamente julgada em 01 de março de 2018, a ADI n. 4275 teve sua tese de repercussão geral fixada para possibilitar aos transgêneros, a partir de então, independentemente de realização de cirurgia de transgenitalização ou de tratamentos hormonais ou patologizantes, a alteração de prenome e sexo diretamente no registro civil. Senão vejamos:

O Tribunal, por maioria, vencidos, em parte, os Ministros Marco Aurélio e, em menor extensão, os Ministros Alexandre de Moraes, Ricardo Lewandowski e Gilmar Mendes, julgou procedente a ação para dar interpretação conforme a Constituição e o Pacto de São José da Costa Rica ao art. 58 da Lei 6.015/73, de modo a reconhecer aos transgêneros que assim o desejarem, independentemente da cirurgia de transgenitalização, ou da realização de tratamentos hormonais ou patologizantes, o direito à substituição de prenome e sexo diretamente no registro civil. (BRASIL, 2018, online)

Diante da decisão, a Corregedoria Nacional de Justiça, órgão do Conselho Nacional de Justiça, regulamentou, no dia 29 de junho de 2018, a referida alteração do assentamento de registro civil através do Provimento n. 73 (CNJ, online), ato normativo que deve ser seguido de maneira uniforme por todos os Cartórios de Registro Civil do país.

O Provimento n. 73 indica que a alteração só será permitida aos maiores de 18 (dezoito) anos, facultando a apresentação de laudo psicológico/médico que ateste a transexualidade/travestilidade do requerente. Segundo a regulamentação, ações em curso não impedem a alteração. Há, ainda, a exigência de apresentação de uma série de documentos ${ }^{10}$ no ato

\footnotetext{
${ }^{10}$ Documentos exigidos: certidão de nascimento atualizada; certidão de casamento atualizada, se for o caso; cópia do registro geral de identidade; cópia da identificação civil nacional, se for o caso; cópia do passaporte brasileiro, se for o caso; cópia do cadastro de pessoa física no Ministério da Fazenda; cópia do título de eleitor; cópia de carteira de identidade social, se for o caso; comprovante de endereço; certidão do distribuidor cível do local de residência dos últimos cinco anos (estadual/federal); certidão do distribuidor criminal do local de residência dos últimos cinco anos (estadual/federal); certidão de execução criminal do local de residência dos últimos cinco anos (estadual/federal); certidão dos tabelionatos de protestos do local de residência dos últimos cinco anos; certidão da Justiça Eleitoral do

Revista de Direito Brasileira | Florianópolis, SC | v. 26 | n. 10 | p. 25-45 | Mai./Ago. 2020
} 
do pedido de alteração, exigência que não é feita quando da averbação de registro civil de pessoa cisgênero, fato que revela a imposição de requisitos demasiados, o que vai contra a natureza da decisão tomada pelo STF em sede de ADI n. 4275. O Provimento n. 73, em seu teor, se refere a alteração de gênero como se sexo fosse, o que indica uma impropriedade terminológica já que a decisão só permitiu a alteração do sexo.

O STF, inclusive, em 15 de agosto de 2018, julgou o Recurso Extraordinário n. $670422^{11}$ (RE n. 670422) e aplicou entendimento semelhante ao utilizado na ADI n. 4275, mas avançou em relação a tese fixada na Ação Direta de Inconstitucionalidade, posto que permitiu a alteração de prenome e classificação de gênero das pessoas trans diretamente no registro civil. A possibilidade de alteração da classificação de gênero impõe avanço significativo que se estende às pessoas transgêneros, visto que compreende o gênero como um artifício fluído e performático, que não está associado à demarcação biológica da pessoa. Esta decisão, então, demonstra o respeito às questões de gênero, situação diferente da observada no julgamento da ADI n. 4275, alvo de críticas neste artigo. No entanto, enquanto não houver aditamento no Provimento n. 73 para adequar-se ao julgamento do RE n. 670422, há uma enorme problemática quanto à eficácia do direito reconhecido em sede de Recurso Extraordinário.

Há, no entanto, uma questão da realidade que não se pode ignorar. Vimos que há múltiplas formas de performatizar o gênero, há, inclusive aquelas pessoas que se veem como trans, porém ainda a partir de uma lógica binária. É preciso também respeitar e acolher esses corpos divergentes que sofrem e significam suas identidades e existências à margem de um sistema cisheteronormativo. A maneira mais inclusiva de acolher a essa diversidade, portanto, é possibilitar e garantir a multiplicidade, a mudança de prenome, a mudança de sexo e a mudança de gênero, sem prévios condicionamentos a autorizações judiciais, ou requisitos médicos, sem patologizações, ou preconceitos, respeitando-se a narrativa de cada ser e a liberdade para ser o que se é.

\section{CONCLUSÕES}

Ante o exposto, a análise da Ação Direta de Inconstitucionalidade $\mathrm{n}^{\circ}$ 4275, a partir do marco teórico proposto, permite concluir que existiu, de fato, um perfil teórico ativista neste julgamento. A propositura e julgamento da ADI 4275 se mostra reflexo do esvaziamento da instituição política, bem como da necessidade de reafirmação, pelo Judiciário, dos direitos de uma minoria que possui direitos morais, questões de princípio não ditos pela norma vigente. A utilização, nos votos dos três Ministros aqui analisados, do princípio da dignidade da pessoa humana como grande propulsor de suas conclusões em favor do exercício do direito ao nome das pessoas trans, reflete a ideia de que todas as pessoas possuem direito a igualdade de consideração e respeito de maneira que as leis não devem ser constituídas deixando pessoas em desvantagem. A filtragem constitucional realizada, bem como a justificação em precedentes da própria Corte, afirmam a ideia do direito como integridade.

Os resultados da pesquisa permitem concluir, ainda, acerca da validação do perfil de gênero binário pela Suprema Corte Brasileira, que embora tenha realizado um ativismo integrador e

\footnotetext{
local de residência dos últimos cinco anos; certidão da Justiça do Trabalho do local de residência dos últimos cinco anos; certidão da Justiça Militar, se for o caso. Ver BRASIL, 2018. Provimento 73. Dispõe sobre a averbação da alteração do prenome e do gênero nos assentos de nascimento e casamento de pessoa transgênero no Registro Civil das Pessoas Naturais (RCPN). Diário de Justiça Eletrônico do CNJ, 29 jun. 2018.

${ }^{11}$ O RE foi proposto contra Acórdão da Oitava Câmara Cível do Tribunal de Justiça do Estado do Rio Grande do Sul, que fixou entendimento no sentido de que a alteração do assentamento civil de pessoa transexual deveria estar condicionada à realização de cirurgia de transgenitalização, alegando como argumentação jurídica o princípio da publicidade e veracidade dos registros públicos. Vide Apelação Cível No 70041776642, Oitava Câmara Cível, Tribunal de Justiça do RS, Relator: Rui Portanova, Julgado em 30/06/2011. Ao RE foi dada repercussão geral e definitivamente julgado pelo STF em agosto/2018.
}

Revista de Direito Brasileira | Florianópolis, SC | v. 26 | n. 10 | p. 25-45 | Mai./Ago. 2020 
simbólico, não se abriu às pluralidades das questões de gênero. Autorizam a conclusão de que, em simbólica monta, o STF reproduziu o discurso que admite apenas a ultrapassada e conservadora ideia do gênero atrelado ao sexo, na qual somente é possível compreender as performances de gênero em número de dois, atreladas ao feminino e ao masculino. O principal argumento que reforça esse entendimento está assentado no fato de que não houve extensão, na tese fixada, para a possibilidade de alteração do gênero no assentamento civil, mas tão somente do sexo. Este posicionamento não leva em consideração a fluidez do gênero e limita a sua performance em feminino e masculino. Portanto, embora tenha havido extensão do direito aos transgêneros, esse direito só atingirá o prenome, ignorando a existência de uma identidade de gênero fluída.

Ademais, o voto do ministro relator, que impôs requisitos médicos a serem auferidos para a afirmação da identidade, "com segurança", das pessoas transexuais, revela a validação de um discurso patologizante, que confirma a ideia de normatização dos corpos que transitam em sua identidade de gênero. Os ministros, mesmo aqueles que seguiram o relator, não impuseram em seu voto qualquer requisito médico. $\mathrm{O}$ debate do relator, então, ocorreu no âmbito dos procedimentos de exclusão, no discurso do regime de verdades, compreendidos como procedimentos sociais utilizados pelo discurso de poder da medicina e do direito para o controle do corpo e dos indivíduos.

A vencer as marcas discursivas do binarismo por uma concepção plural de gênero, o julgamento da ADI 4275 revela-se um grande e poderoso marco na afirmação dos direitos fundamentais das pessoas trans, identidades frequentemente silenciadas pelo discurso de poder hegemônico. O direito ao nome, sem dúvida, é um dos mais expressivos direitos individuais que ventilam a dignidade da pessoa humana. Nome é pertencimento, primeira instância na qual a pessoa humana se reconhece, afirma sua identidade, que a marca para a posteridade. Nome é o lar da pessoa, lar do mais íntimo sentimento de ser, de estar, para si e para o mundo. E mais importante do que viver é viver com dignidade, em espaço de muito mais do que a simples tolerância, mas de consideração e de respeito. A partir do julgamento da ADI 4275, com sua força vinculante, as pessoas trans finalmente têm prenunciada sua tão custosa dignidade.

\section{REFERÊNCIAS}

AURÉLIO, Marco. Voto em Ação Direta de Inconstitucionalidade n. 4275/DF. Brasília: Supremo Tribunal Federal, 2018. Disponível em: <http://www.stf.jus.br/arquivo/cms/noticiaNoticiaStf/anexo/ADI4.275VotoMMA.pdf> Acesso em: 09 abr. 2018.

BARROSO, Luis Roberto. Judicialização, ativismo judicial e legitimidade democrática. Anuario Iberoamericano de Justicia Constitucional ISSN 1138-4824, núm. 13, Madrid, 2009, p. 17-32. Disponível em:

$<$ https://dialnet.unirioja.es/servlet/articulo? codigo $=5124286 \&$ orden $=0 \&$ info $=$ link $>$. Acesso em: 30 set. 2018 .

BENTO, Berenice. O que é transexualidade. São Paulo: Brasiliense, 2008.

BRASIL. Constituição da República Federativa do Brasil de 1988. Diário Oficial da União, 5 out. 1988

. Lei n. 6.015, de 31 de dezembro de 1973. Dispõe sobre os registros públicos, e dá outras providências. Diário Oficial da União, 31 dez. 1973.

Conselho Nacional de Justiça. Provimento 73. Dispõe sobre a averbação da alteração do prenome e do gênero nos assentos de nascimento e casamento de pessoa transgênero no Registro 
Civil das Pessoas Naturais (RCPN). Diário de Justiça Eletrônico do CNJ, 29 jun. 2018.

Supremo Tribunal Federal. Ação direta de inconstitucionalidade n. 4275/DF.

Requerente: Procuradoria Geral da República. Relator: Min. Marco Aurélio. Diário da Justiça Eletrônico, 06 mar. 2018.

Supremo Tribunal Federal. Arguição de descumprimento de preceito fundamental n. 132/RJ. Requerente: Governador do Estado do Rio de Janeiro. Relator: Min. Ayres Britto. Diário da Justiça Eletrônico, 13 out. 2011.

Supremo Tribunal Federal. Arguição de descumprimento de preceito fundamental n. 186/DF. Requerente: Partido Democratas. Relator: Min. Ricardo Lewandowski. Diário da Justiça Eletrônico, 26 abr. 2012.

BUTLER, Judith. Problemas de gênero: feminismo e subversão da identidade. Rio de Janeiro: Civilização Brasileira, 2003.

CARVALHO, Mario; CARRARA, Sérgio. Em direção a um futuro trans? Contribuição para a história do movimento de travestis e transexuais no Brasil. In: Sexualidad, Salud y Sociedad: Revista Latinoamericana. d. 2, n. 14, 2013, p. 319-351. Disponível em: <https://www.epublicacoes.uerj.br/index.php/SexualidadSaludySociedad/article/view/6862/4940> Acesso em: 23 nov. 2018.

CONSELHO NACIONAL DE JUSTIÇA. Corregedoria normatiza troca de nome e gênero em cartório. Disponível em: <http://www.cnj.jus.br/noticias/cnj/87092-corregedoria-normatiza-trocade-nome-e-genero-em-cartorio> Acesso em: 23 nov. 2018.

CUNHA JÚNIOR, Dirley da. Curso de Direito Constitucional. 12. ed. rev. ampl. atual. Salvador: Juspodivm, 2018.

DAHL, Robert. A democracia e seus críticos. Tradução de: Patrícia de Freitas Ribeiro. São Paulo: Martins Fontes, 2012.

DELEUZE, Gilles; GUATTARI, Félix. O que é a filosofia?. trad. Bento Prado Jr. e Alberto Alonso Munõz. 3. ed. São Paulo: Ed. 34, 2010.

DIDIER JÚNIOR, Fredie. Curso de direito processual civil. 17. ed. Salvador: JusPODIVM, 2015. 1v.

DWORKIN, Ronald. Levando os direitos a sério. trad. Nelson Boeira. 3. ed. São Paulo: Martins Fontes, 2010.

ELY, John Hart. Democracia e Desconfiança. Uma Teoria do Controle Judicial de Constitucionalidade. Trad. Juliana Fontes. São Paulo: Martins Fontes, 2010.

FACHIN, Edson. Voto em Ação Direta de Inconstitucionalidade n. 4275/DF. Brasília: Supremo Tribunal Federal, 2018. Disponível em:

<http://www.stf.jus.br/arquivo/cms/noticiaNoticiaStf/anexo/ADI4.275VotoEF.pdf> Acesso em: 09 abr. 2018.

FERRAJOLI, Luigi. Direito e razão: teoria do garantismo penal. $3^{\mathrm{a}}$ ed. São 
Paulo: Editora Revista dos Tribunais, 2010.

FOUCAULT, Michel. Microfísica do poder. Organização e tradução de Roberto Machado. Rio de Janeiro: Edições Graal, 1979.

. História da sexualidade I: a vontade de saber. Rio de Janeiro: Graal, 1998.

A ordem do discurso. 24. ed. São Paulo: Loyola, 2015 (Coleção Leituras Filosóficas).

GARAPON, Antoine. O juiz e a democracia: o guardião de promessas. 2. ed. Rio de Janeiro:

Revan, 2001.

GOHN, Maria da Glória. Movimentos Sociais na Contemporaneidade. In: Revista Brasileira de Educação. v. 16, n. 47, 2011, p. 333-361. Disponível em:

<http://www.scielo.br/pdf/rbedu/v16n47/v16n47a05.pdf> Acesso em: 23 nov. 2018.

MORAES, Alexandre de. Voto em Ação Direta de Inconstitucionalidade n. 4275/DF. Brasília: Supremo Tribunal Federal, 2018.

RICH, A. Heterossexualidade compulsória e existência lésbica. Bagoas - Estudos gays: gêneros e sexualidades, v. 4, n. 05, 27 nov. 2012.

SCOTT, Joan W. Gênero: uma categoria útil de análise histórica. Educação e Realidade, vol. 16, n. 2, Porto Alegre, jul./dez. 1990.

SUPREMO TRIBUNAL FEDERAL. STF reconhece a transgêneros possibilidade de alteração de registro civil sem mudança de sexo. Disponível em:

<http://www.stf.jus.br/portal/cms/verNoticiaDetalhe.asp?idConteudo=371085> Acesso em: 14 maio 2018.

SUNSTEIN, Cass R. One case at a time: judicial minimalism on the Supreme Court. 2. ed. Massachusetts: Harvard University Press, 2001. 